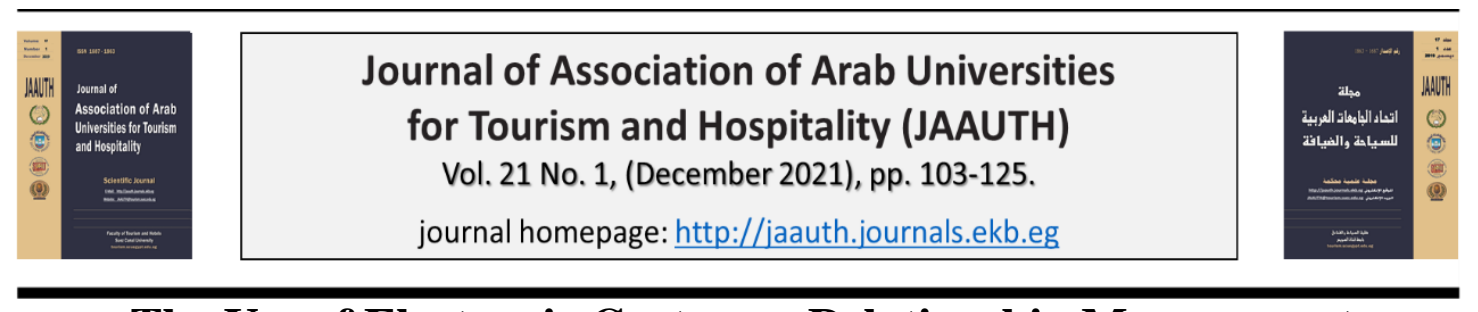

\title{
The Use of Electronic Customer Relationship Management (E-CRM) Features through Hotel' Website to Enhance Customer Loyalty and Brand Image
}

\author{
Yasser Ibrahim \\ Professor at Galala University; Faculty of \\ Tourism and Hotel Management, Helwan \\ University \\ E-mail: Yasser.Ibrahim@FTH.Helwan.edu.eg
}

\begin{abstract}
Tamer Mohamed Abbas
Professor at the Faculty of Tourism and Hospitality, King Salman International University; Faculty of Tourism and Hotel Management, Helwan University E-mail: tamerabbas@yahoo.com
\end{abstract}

\section{Mohamed Ahmed Kamal}

Faculty of Tourism and Hotel Management, Helwan University, Cairo, Egypt, E-mail: moh.kamal_hotel@yahoo.com

\section{ARTICLE INFO \\ Keywords: \\ Electronic Customer \\ Relationship \\ Management \\ (eCRM); Customer \\ Loyalty; Brand \\ Image; Structural}

Equation Modeling

(SEM); Greater Cairo hotels.

\section{(JAAUTH)}

Vol. 21, No. 1, (December 2021), PP.103-125.

\section{ABSTRACT}

Despite the tremendous importance of electronic customer relationship management (eCRM), customer loyalty, and brand image in the hospitality industry, literature has revealed limited research into this aspect in hotels. The study objectives are to explore the influence of using eCRM practices (ease of use / navigation, information quality, personalization level, payment options, site security and privacy policies, reservation and tracking, price attractiveness, and multimedia features,) to enhance customer loyalty and brand image in hotels. A conceptual framework for the study was constructed based on the pertinent literature and pilot study. The study relied on questionnaires as a tool for data collection. The survey was compiled based on previous studies, and it was distributed to hotel guests in twenty different five-star hotels in Great Cairo. The researchers distributed 400 questionnaires to a random sample of hotel' guests in 20 hotels, 277 were valid, with an acceptable response rate of $69.25 \%$. The valid data was analyzed through (SPSS V.25) and Structural Equation Modeling (SEM) using (AMOS V.20). The findings revealed that ease of use / navigation, information quality, personalization level, payment options, site security and privacy policies, reservation and tracking, and price attractiveness significantly impact customer loyalty in hotels. Also, customer loyalty significantly affects the brand's image. Additionally, electronic customer relationship management (eCRM) through customer loyalty significantly impacts the brand's image.

\section{Introduction}

The hospitality industry is one of the world's largest and quickest-growing service sectors, contributing significantly to the economic and social development of many 
countries. Customer-oriented industries have emerged in the modern era, and customer relations and their impact on loyalty have emerged as critical tasks for hotel management (Khadka \& Maharjan, 2017).

The Internet has altered the traditional hotel reservation procedure. As a consequence, prospective consumers may quickly compare the rooms and rates of various hotels. Guests may use virtual tours to explore the inside and outside of the hotel, giving them a sense of what to expect when they arrive. Clients can now easily acquire information on hotel rooms, prices, advantages, and promotions, and as a result, competition amongst hotels to attract and keep customers is fierce (Milović, 2012).

As described by Zafar, et al., (2012), attracting new customers costs 5 to 6 times more than keeping existing ones (Ata \& Toker, 2012). Accordingly, this paper explores how hotels may use eCRM practices to manage customer relationships to achieve customer loyalty, since customer loyalty is a very important aspect of hotels in an online environment.

Brand image is considered as a worthy antecedent of customer satisfaction and loyalty. Brand image is important because positive and good brand image support organizations to achieve higher performance and revenues. Customer loyalty is directly affected by brand image (Yu-TeTu \& Hsu, 2013).

\section{Literature review}

\subsection{Electronic Customer Relationship Management (eCRM)}

No industry seems to be more interested in forming permanent relationships with its customers than the hospitality industry. With the arrival of new technologies and the internet, a new approach to CRM has appeared and is termed as Electronic CRM (eCRM) or Online CRM (Bradway \& Purchia, 2000; Azila \& NoorNeeraj, 2011).

As a result, organizations are eager to implement various sorts of eCRM tactics in order to obtain, retain, and develop client connections that are helpful to loyalty and the organization's success (Dawn and Chowdhury, 2011). According to many researchers, the relationship between eCRM and customer loyalty, such as the one mentioned above, means that the more customers are satisfied, repurchase, and spread positive word of mouth about the service provider, the more they tend to perceive longer relationships, trust, and commitment with the service provider (Azila and NoorNeeraj, 2011; Safa and Ismail, 2013; Safa et al., 2016). According to Bashir et al., (2017), it is necessary to develop long-term relationships with clients since having a loyal client base is a need in this day and age. According to Adejumo (2019), eCRM infrastructure aids valuable and important customers in remaining loyal because information kept in the eCRM data base, for example, supports a firm in determining the true cost of acquiring and maintaining consumers

Today, businesses have realized the fact that they can only compete with competitors by building strong relationships with its customers through the Internet (Dawn \& Chowdhury, 2011). Hamid \& McGrath (2005) and Ab Hamid et al., (2011) listed eCRM practices on websites as ease of use / navigation, information quality, 
personalization level, payment options, site security / privacy, price attractiveness, and multimedia features.

\subsection{Customer Loyalty}

Losing customers is considered to be very expensive for any profit-oriented enterprise, since a loyal customer spends more, typically exhibits a higher propensity to spend on the organization's services, and frequently works as an ambassador and advocate for the firm to other consumers (Harris \& Goode, 2004). So, one of the most critical jobs confronting organizations in today's competitive business climate is the capacity of a firm to create and sustain strong long-term partnerships with a sizable portion of its market share (Oluwafemi \& Adebiyi, 2018).

Customers, on the other hand, diversify their portfolio of services and products from service providers, diminishing the particular firm's market share (Aurier \& N'Goala, 2010). Given that the relationship between loyalty and financial performance has been accepted (Hallowell, 1996; Anderson \& Mittal 2000; Edvardsson et al., 2000; Anderson \& Mansi 2009; Fornell et al., 2009). Considering the fact that it is less expensive to maintain a customer than to acquire a new one, establishing long-term connections and cultivating consumer loyalty have emerged as critical issues in marketing (Athanasopoulou, 2009; Oluwafemi \& Adebiyi, 2018).

\subsection{Brand Image}

Pan \& Zinkhan, (2006) defined brand image as the way in which a brand is perceived in the customer's mind. A brand image is also defined as a customer's feelings and thoughts about the brand (Roy \& Banerjee, 2007). In today's competitive business world, an organization's brand image, such as the products or services supplied, is extremely significant. The majority of businesses regard their brand image as a valuable asset to their success (Kariuki, 2015). Customers are more likely to utilize a firm's products or services if it has a trusted and recognized brand identity. Researchers have advised that a good image may create more loyal customers; as a result, successful firms work hard to establish a strong brand and portray it in a consistent and unambiguous manner (Puri, 2017).

\subsection{The Research Hypotheses}

\subsubsection{Relationship between Ease of use and Customer Loyalty}

Ease of use / navigation is considered as an important aspect of a satisfying online experience, as a smooth website leads to satisfaction and loyalty to the organization (Cai \& Xu, (2006). Therefore, this research suggests that ease of use and navigation leads to loyalty.

H1: Ease of use / navigation has a positive impact on loyalty.

\subsubsection{Relationship between Information quality and Customer Loyalty}

Information quality has been mentioned in many research studies. In reference to Choi, et al., (2013), if the operator of a website provides valuable information to customers, then customers will begin to trust the information they receive from the website. A site that offers expired and not accurate information may be viewed as 
inefficient (Gorla, et al., 2010; Ab Hamid et al., 2011). Therefore, this research suggests that proper information quality on hotels' websites results in customer loyalty. Based on this, the hypothesis can be formulated as follows:

H2: Information quality has a positive impact on loyalty.

\subsubsection{Relationship between Personalization level and Customer Loyalty}

Personalized service should be better than routine and ordinary service that does not give attention to guests' individual needs (Peppers \& Rogers, 2011). Personalization has been assumed to lead to satisfaction and loyalty (Chung, et al., 2016). Based on this, the following hypothesis can be formulated:

H3: Personalization level have a positive impact on loyalty.

\subsubsection{Relationship between Payment options, site security and privacy policies and Customer Loyalty}

Usually, customers are worried about their security and privacy while dealing online, especially regarding payment and providing personal information. Security assurance on the web could be implemented by different methods such as digital certificates and thirdparty agencies which help customers to feel safe online (Ab Hamid et al., 2011; Cherapanukorn, 2017). Based on this, the following hypothesis can be formulated:

H4: Payment options, site security and privacy policies have a positive impact on loyalty.

\subsubsection{Relationship between Reservation and tracking and Customer Loyalty}

Ab Hamid et al., (2011) mentioned that hotels should apply some facilities to their websites, such as reservations and history tracking, and allow guests to edit their reservations online easily. Based on this, the following hypothesis can be formulated:

H5: Reservation and tracking have a positive impact effect on loyalty.

\subsubsection{Relationship between Price attractiveness and Customer Loyalty}

Ab Hamid, et al., (2011) mentioned that online customers can check and review rates through hotel websites easily. Therefore, if customers find lower prices for the same services anywhere else, they become less satisfied and less loyal. Based on this, the following hypothesis can be formulated:

H6: Price attractiveness / lower rates have a positive impact on loyalty.

\subsubsection{Relationship between Multimedia features and Customer Loyalty}

According to Ab Hamid et al. (2011), organizations can benefit from publishing high quality images and videos presenting the quality of services provided by the hotel, as well as adding background music that helps customers relax and motivates them to reserve, which leads to loyalty over time. Based on this, the following hypothesis can be formulated:

H7: Multimedia features have a positive impact on loyalty.

\subsubsection{Relationship between Customer Loyalty and Brand Image}


Ogba \& Tan, (2009) and Yu-TeTu \& Hsu, (2013) mentioned that brand image has been considered as one of the most important pillars of loyalty. Saleem \& Raja, (2014) mentioned that there is a significant relationship between customer loyalty and brand image. Based on this, the following hypothesis can be formulated:

H8: Customer loyalty has an effect on brand image.

Following these views, eight hypotheses and a proposed model (see Fig. 1) are presented below.

H1: Ease of use / navigation has a positive impact on loyalty.

H2: Information quality has a positive impact on loyalty.

H3: Personalization level has a positive impact on loyalty.

H4: Payment options, site security and privacy policies has a positive impact on loyalty.

H5: Reservation and tracking has a positive impact on loyalty.

H6: Price attractiveness / lower rates have a positive impact on loyalty.

H7: Multimedia features have a positive impact on loyalty.

H8: Customer loyalty has a positive impact on brand image.

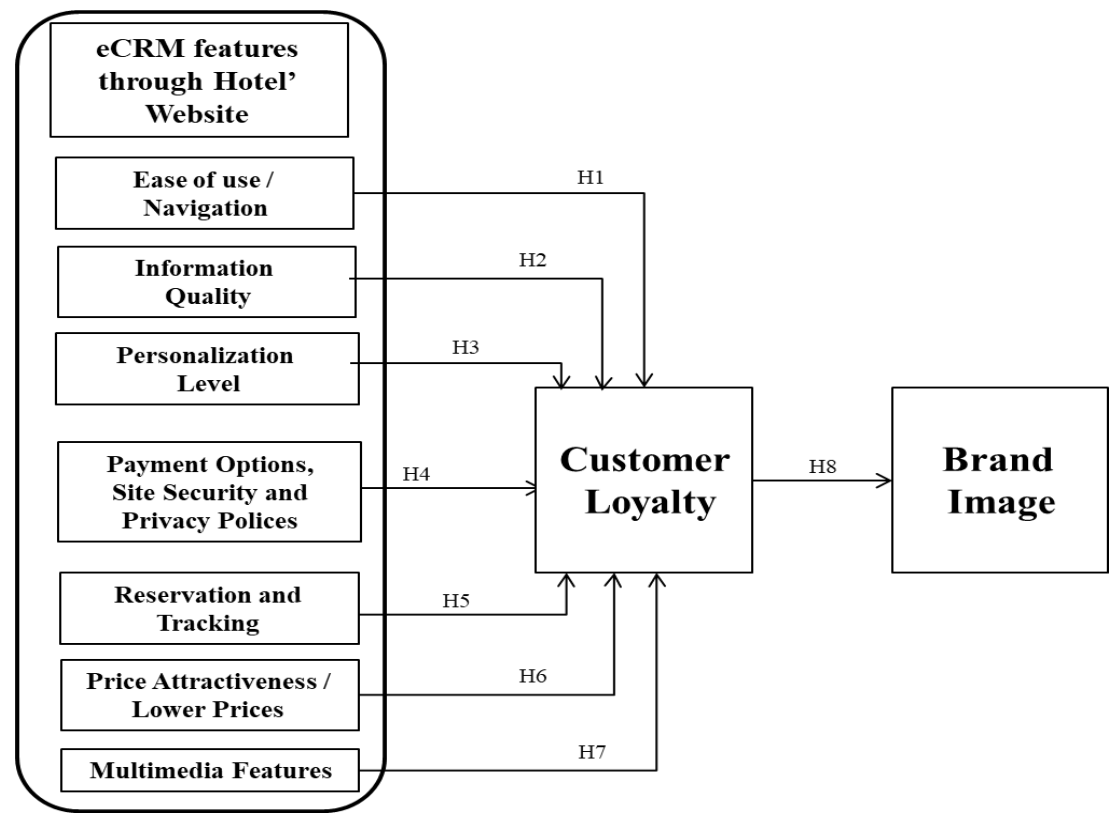

Fig. 1. Proposed research model of the association between

eCRM features through Hotel' Website, customer loyalty and brand image in hotels

\section{Research methodology}

This study provides an investigation of the interrelationship between eCRM features on hotels' websites and customer loyalty in the hotel sector. The study's aim is to identify the impact of eCRM on hotel guests' loyalty. A questionnaire was distributed from Sep. 2019 through Feb. 2020. This questionnaire was conducted with 277 hotels' guests from 20 hotels applied eCRM using a convenience sampling technique. 


\subsection{Survey Structure}

The study used a questionnaire survey as the data-collecting tool. ECRM, customer loyalty, and brand image elements scales were adapted and revised from (Kim, et al., 2004; Ab Hamid et al., 2011; Cherapanukorn, 2017). The survey was reviewed by hotel managers with over ten years of experience, as well as a random sample of hotel guests. The final copy of the survey was divided into four main parts. The first part asked hotel guests for demographic information (i.e., sex, age, educational level, occupation, and monthly income). The second section includes 30 items on a five-point Likert-scale ranging from 'never' (1) to 'always' (5) that ask guests about how the hotel uses electronic customer relationship management (eCRM) features via the hotel website. In the third and fourth sections, they were asked to rate 5 and 10 items on a five-point Likert-scale ranging from 'strongly disagree' (1) to 'strongly agree' (5), to assess their hotel loyalty and brand image. The 45 items are divided into nine variables: ease of use / navigation ( 7 items), information quality (4 items), personalization level (3 items), payment options, site security and privacy policies ( 3 items), reservation and tracking (5 items), price attractiveness / lower rates (4 items), multimedia features (4 items), customer loyalty (5 items), and brand image (10 items).

\subsection{Research Population and Sampling Technique}

The target population for this study was five-star hotel guests in greater Cairo. The researchers distributed 400 questionnaires to a random sample of hotel' guests in 20 hotels, 277 were valid, with an accepted response rate of $69.25 \%$ (See table 1).

\section{Table 1}

Hotel' Guests Response Rate

\begin{tabular}{|c|c|c|c|c|c|c|c|c|c|}
\hline S & $\begin{array}{c}\text { Code of } \\
\text { Hotel }\end{array}$ & Fistributed & $\begin{array}{c}\text { Collected } \\
\text { F Valid }\end{array}$ & $\begin{array}{c}\text { Valid } \\
\text { Forms }\end{array}$ & Percentage & S & $\begin{array}{c}\text { Code of Distributed } \\
\text { Hotel }\end{array}$ & $\begin{array}{c}\text { Collected } \\
\text { F Varms } \\
\text { Forms }\end{array}$ & $\begin{array}{c}\text { Valid } \\
\text { Percentage }\end{array}$ \\
\hline 1 & H\# 01 & 20 & 15 & $75 \%$ & 11 & H\# 11 & 20 & 15 & $75 \%$ \\
\hline 2 & H\# 02 & 20 & 14 & $70 \%$ & 12 & H\# 12 & 20 & 14 & $70 \%$ \\
\hline 3 & H\# 03 & 20 & 15 & $75 \%$ & 13 & H\# 13 & 20 & 13 & $65 \%$ \\
\hline 4 & H\# 04 & 20 & 14 & $70 \%$ & 14 & H\# 14 & 20 & 12 & $60 \%$ \\
\hline 5 & H\# 05 & 20 & 11 & $55 \%$ & 15 & H\# 15 & 20 & 17 & $85 \%$ \\
\hline 6 & H\# 06 & 20 & 12 & $60 \%$ & 16 & H\#16 & 20 & 12 & $60 \%$ \\
\hline 7 & H\# 07 & 20 & 12 & $60 \%$ & 17 & H\# 17 & 20 & 15 & $75 \%$ \\
\hline 8 & H\# 08 & 20 & 15 & $75 \%$ & 18 & H\# 18 & 20 & 15 & $75 \%$ \\
\hline 9 & H\# 09 & 20 & 15 & $75 \%$ & 19 & H\# 19 & 20 & 15 & $75 \%$ \\
\hline 10 & H\# 10 & 20 & 12 & $60 \%$ & 20 & H\# 20 & 20 & 14 & $70 \%$ \\
\hline \multicolumn{2}{|c|}{ Total } & 400 & 277 & $69.25 \%$ & \multicolumn{7}{|c|}{} \\
\hline
\end{tabular}

\subsection{Data Analysis}

This research adopted three aspects to analyze data, first one was checking for incomplete data to consider it not valid and exclude it from analysis, second one was data coding to all constructs so ease of use / navigation questions were coded from EU1 to EU7, information quality questions were coded from IQ1 to IQ4, personalization level questions were coded from PL1 to PL3, payment options, site security and privacy policies questions were coded 
from PS1 to PS3, reservation and tracking questions were coded from RT1 to RT5, price attractiveness questions were coded from PA1 to PA4, multimedia features questions were coded from MF1 to MF4, customer loyalty questions were coded from CL1 to CL5, and brand image questions were coded from BI1 to BI10.

For the descriptive analysis, SPSS V.25 was used to analyze the relationship between eCRM practices, customer loyalty and the brand image scale descriptively. On the other hand, (SEM) was used to test the measurement model of eCRM, customer loyalty and brand image using AMOS V.20. The questionnaire items are listed in Table 2, with their mean, standard deviation, and mean rank.

\section{Table 2}

Construct measurements

\begin{tabular}{|c|c|c|c|c|c|}
\hline Construct & $\begin{array}{c}\text { Cod } \\
\mathrm{e}\end{array}$ & Measure & Mean & $\begin{array}{l}\text { Std. } \\
\text { Dev. }\end{array}$ & $\begin{array}{l}\text { Mean } \\
\text { Rank }\end{array}$ \\
\hline \multirow{7}{*}{$\begin{array}{l}\text { Ease of Use } \\
\quad(\mathbf{E U})\end{array}$} & EU1 & a) Website is always easily accessible & 4.09 & 0.77 & 1 \\
\hline & EU2 & b) I can get information easily & 3.80 & 0.79 & 5 \\
\hline & EU3 & c) Web pages load quickly & 4.04 & 0.82 & 2 \\
\hline & EU4 & d) Links to information are clearly displayed & 3.78 & 0.82 & 6 \\
\hline & EU5 & e) Language and terms are easily understood & 3.84 & 0.82 & 4 \\
\hline & EU6 & f) Website offers multiple language options & 3.92 & 1.13 & 3 \\
\hline & EU7 & $\begin{array}{l}\text { g) Website URL address is easy to } \\
\text { remember }\end{array}$ & 3.55 & 0.91 & 7 \\
\hline \multirow{4}{*}{$\begin{array}{l}\text { Information } \\
\text { Quality (IQ) }\end{array}$} & IQ1 & a) Information displayed is accurate & 3.92 & 0.76 & 1 \\
\hline & IQ2 & $\begin{array}{l}\text { b) The site provides in-depth information on } \\
\text { services }\end{array}$ & 3.67 & 0.88 & 3 \\
\hline & IQ3 & $\begin{array}{l}\text { c) Website' information illustrates real } \\
\text { quality of services }\end{array}$ & 3.90 & 0.85 & 2 \\
\hline & IQ4 & $\begin{array}{l}\text { d) Website' information illustrates real } \\
\text { condition of services }\end{array}$ & 3.57 & 0.87 & 4 \\
\hline \multirow{3}{*}{$\begin{array}{l}\text { Personalizat } \\
\text { ion Level } \\
\text { (PL) }\end{array}$} & PL1 & a) I can view my transaction history & 2.75 & 1.45 & 3 \\
\hline & PL2 & $\begin{array}{l}\text { b) Receive promotional information that } \\
\text { match my interests }\end{array}$ & 3.34 & 1.24 & 1 \\
\hline & PL3 & c) I can create an account on the website & 3.14 & 1.70 & 2 \\
\hline \multirow{3}{*}{$\begin{array}{c}\text { Payment } \\
\text { Options, } \\
\text { Site } \\
\text { Security, } \\
\text { and Privacy } \\
\text { Policies } \\
\text { (PS) } \\
\end{array}$} & PS1 & a) I can pay with different credit card types & 4.43 & 0.74 & 1 \\
\hline & PS2 & b) Website imposes a strict privacy policy & 4.42 & 0.76 & 2 \\
\hline & PS3 & $\begin{array}{l}\text { c) High security standard over transaction } \\
\text { data }\end{array}$ & 4.33 & 0.78 & 3 \\
\hline \multirow{2}{*}{$\begin{array}{c}\text { Reservation } \\
\text { and } \\
\text { Tracking } \\
\end{array}$} & RT1 & a) Hotel allows to view my reservation & 3.61 & 1.26 & 1 \\
\hline & RT2 & $\begin{array}{l}\text { b) Make changes to online reservation } \\
\text { without much hassle }\end{array}$ & 3.39 & 1.15 & 3 \\
\hline & & & & \multicolumn{2}{|c|}{ Continued } \\
\hline
\end{tabular}




\begin{tabular}{|c|c|c|c|c|c|}
\hline \multirow[t]{3}{*}{ (RT) } & RT3 & c) I can order a tailored service & 3.33 & 1.22 & 4 \\
\hline & RT4 & d) Hotel understands my needs & 3.50 & 1.11 & 2 \\
\hline & RT5 & $\begin{array}{l}\text { e) Hotel keeps track of my online } \\
\text { transactions }\end{array}$ & 3.20 & 1.21 & 5 \\
\hline \multirow{4}{*}{$\begin{array}{c}\text { Price } \\
\text { Attractivene } \\
\text { ss / Lower } \\
\text { Rates (PA) }\end{array}$} & PA1 & a) Website has reasonable price options & 3.36 & 1.01 & 1 \\
\hline & PA2 & b) The site offers attractive discounts & 3.13 & 1.15 & 2 \\
\hline & PA3 & c) The site offers attractive promotions & 3.00 & 1.17 & 4 \\
\hline & PA4 & $\begin{array}{l}\text { d) Services prices are lower than others } \\
\text { (Best rate Guarantee) }\end{array}$ & 3.09 & 1.07 & 3 \\
\hline \multirow{4}{*}{$\begin{array}{l}\text { Multimedia } \\
\text { Features } \\
\text { (MF) }\end{array}$} & $\begin{array}{c}\mathrm{MF} \\
1\end{array}$ & a) Website offers entertainment features & 2.46 & 1.16 & 3 \\
\hline & $\begin{array}{c}\mathrm{MF} \\
2\end{array}$ & $\begin{array}{l}\text { b) I enjoy listen to a music through hotel' } \\
\text { website }\end{array}$ & 1.36 & 0.95 & 4 \\
\hline & $\begin{array}{c}\mathrm{MF} \\
3\end{array}$ & c) Website displays attractive pictures & 4.14 & 0.87 & 1 \\
\hline & $\begin{array}{c}\mathrm{MF} \\
4\end{array}$ & $\begin{array}{l}\text { d) Website has the multimedia and } \\
\text { animation effects }\end{array}$ & 3.37 & 1.20 & 2 \\
\hline \multirow{5}{*}{$\begin{array}{l}\text { Customer } \\
\text { Loyalty } \\
\text { (CL) }\end{array}$} & CL1 & a) I will propose the hotel to others & 3.31 & 1.07 & 4 \\
\hline & CL2 & b) I will advise relatives to visit the hotel & 3.22 & 1.09 & 5 \\
\hline & CL3 & $\begin{array}{l}\text { c) I intend to revisit/continue using this } \\
\text { hotel }\end{array}$ & 3.63 & 1.06 & 1 \\
\hline & CL4 & $\begin{array}{l}\text { d) I will consider the hotel as my best } \\
\text { choice when I need hotel service }\end{array}$ & 3.39 & 1.01 & 3 \\
\hline & CL5 & $\begin{array}{l}\text { e) I would like to stay in this hotel next time } \\
\text { / would not switch to another hotel }\end{array}$ & 3.53 & 1.05 & 2 \\
\hline \multirow{10}{*}{$\begin{array}{c}\text { Brand } \\
\text { Image (BI) }\end{array}$} & BI1 & a) This hotel is comfortable for me & 3.83 & 0.92 & 2 \\
\hline & BI2 & b) This hotel offers a high level of service & 3.70 & 1.02 & 4 \\
\hline & $\mathrm{BI} 3$ & c) This hotel has a very clean image & 3.63 & 1.02 & 6 \\
\hline & BI4 & d) This hotel is luxurious & 3.67 & 1.04 & 5 \\
\hline & BI5 & e) This hotel is expensive & 3.78 & 0.91 & 3 \\
\hline & BI6 & $\begin{array}{l}\text { f) This hotel is a suitable place for high } \\
\text { class }\end{array}$ & 3.45 & 1.01 & 9 \\
\hline & BI7 & g) I feel special by visiting this hotel & 3.51 & 1.03 & 7 \\
\hline & BI8 & h) The staff is very kind & 3.93 & 0.88 & 1 \\
\hline & BI9 & i) I have a long history with this hotel & 3.30 & 1.04 & 10 \\
\hline & $\begin{array}{c}\text { BI1 } \\
0\end{array}$ & j) This hotel has a unique image & 3.46 & 1.04 & 8 \\
\hline
\end{tabular}

\subsection{Analysis of Findings}

\subsubsection{Respondents' Profiles}

The demographic profile of respondents varied (as presented in table 3) as hotel guests were from various age sets, with the largest group being 18 years to 40 years (i.e., 46.21 percent), while the lowest age group was more than 50 years (i.e., 23.47 
percent). The guests were comprised (i.e., 56.68 percent) of males and (i.e., 43.32 percent) of females. In terms of education, the majority of guests had a university degree (i.e., 63.54 percent). With regards to occupation, the majority of hotel guests are executives (i.e., 60.65 percent). Finally, the majority of hotel guests (63.54 percent) earn more than 20,000 LE of their monthly income. Table 3 depicts the demographic characteristics of the guests who stayed in five-star hotels in Greater Cairo.

Table 3

Demographic Characteristics (N=277)

\begin{tabular}{|c|l|c|c|}
\hline \multicolumn{2}{|c|}{ Demographic Data (Variables) } & Frequency & Percentage \% \\
\hline \multirow{4}{*}{ Gender } & Male & 157 & $56.68 \%$ \\
\cline { 2 - 4 } & Female & 120 & $43.32 \%$ \\
\hline \multirow{3}{*}{ Educational Level } & 18 up to 40 & 128 & $46.21 \%$ \\
\cline { 2 - 4 } & More than 40 up to 50 & 84 & $30.32 \%$ \\
\cline { 2 - 4 } & More than 50 & 65 & $23.47 \%$ \\
\cline { 2 - 4 } & Secondary & 1 & $00.36 \%$ \\
\cline { 2 - 4 } & University & 176 & $63.54 \%$ \\
\hline \multirow{4}{*}{ Occupation } & Postgraduate & 100 & $36.10 \%$ \\
\cline { 2 - 4 } & Exon-executive & 72 & $25.99 \%$ \\
\cline { 2 - 4 } & Pensioner & 168 & $60.65 \%$ \\
\hline & Less than 5000 LE & 37 & $13.36 \%$ \\
\cline { 2 - 4 } & $5001-10000$ LE & 12 & $0.72 \%$ \\
\cline { 2 - 4 } & $10001-20000$ LE & 87 & $31.43 \%$ \\
\cline { 2 - 4 } & More than 20000 LE & 176 & $63.54 \%$ \\
\hline
\end{tabular}

\subsubsection{Structural Equation Modeling}

\subsubsection{Confirmatory Factor Analysis}

The reliability and validity of the seven eCRM practices scale, the customer loyalty scale, and the brand image scale were assessed using CFA. The initial model was not acceptable, so some modification indices were proposed to increase model fit. So, some items were removed (EU- 1, EU- 3, EU- 6, EU- 7, IQ- 1, IQ- 2, PL- 2, RT- 2, RT- 3, and BI- 5) (Finally, an acceptable model fit succeeded: Index of incremental fit $($ IFI $)=0.953$, index of Tucker-Lewis $($ TLI $)=0.945$, index of comparative fit ( CFI $)=0.952$, which were all greater than the recommended level of 0.90 , and root mean square error of approximation ( RMSEA ) $=0.053$, lower than the cut off value of 0.06 (Hu \& Bentler, 1999 and Steiger, 2007) (see Table 6). The results of CFA showed that the lowermost rate of CR and Cronbach's $\alpha$ for all of constructs was 0.856, which beat the acceptable value of 0.70 (Pallant, 2020), proving that the statistics are reliable. Additionally, the values of Average Variance Extracted (AVE) for all constructs surpassed the acceptable value of 0.50 representing good convergent validity (Hair et al., 2006) (see Table 4). Furthermore, the results of CFA (see Table 5) show that the AVE of each construct was greater than the squared correlation for each of the different two constructs, representing good discriminant validity (Hair, et al., 2006). 
Table 4

Discriminant validity and correlation matrix

\begin{tabular}{|c|c|c|c|c|c|c|c|c|}
\hline Construct & EU & IQ & PL & PS & RT & PA & CL & BI \\
\hline EU & $\mathbf{0 . 6 9 5}$ & & & & & & & \\
\hline IQ & 0.517 & $\mathbf{0 . 7 7 8}$ & & & & & & \\
\hline PL & 0.137 & 0.171 & $\mathbf{0 . 7 5 7}$ & & & & & \\
\hline PS & 0.264 & 0.398 & 0.255 & $\mathbf{0 . 8 5 2}$ & & & & \\
\hline RT & 0.575 & 0.585 & 0.424 & 0.530 & $\mathbf{0 . 7 4 8}$ & & & \\
\hline PA & 0.402 & 0.456 & 0.454 & 0.542 & 0.740 & $\mathbf{0 . 8 2 7}$ & & \\
\hline CL & 0.588 & 0.570 & 0.327 & 0.264 & 0.579 & 0.469 & $\mathbf{0 . 8 1 3}$ & \\
\hline BI & 0.555 & 0.648 & 0.164 & 0.274 & 0.567 & 0.398 & 0.704 & $\mathbf{0 . 7 5 9}$ \\
\hline
\end{tabular}

Notes: Bold numbers represent AVE of the constructs, while other numbers represent the squared correlations of each two constructs

\section{Table 5}

Factor loadings, validity analysis, and reliability test of the measurement model

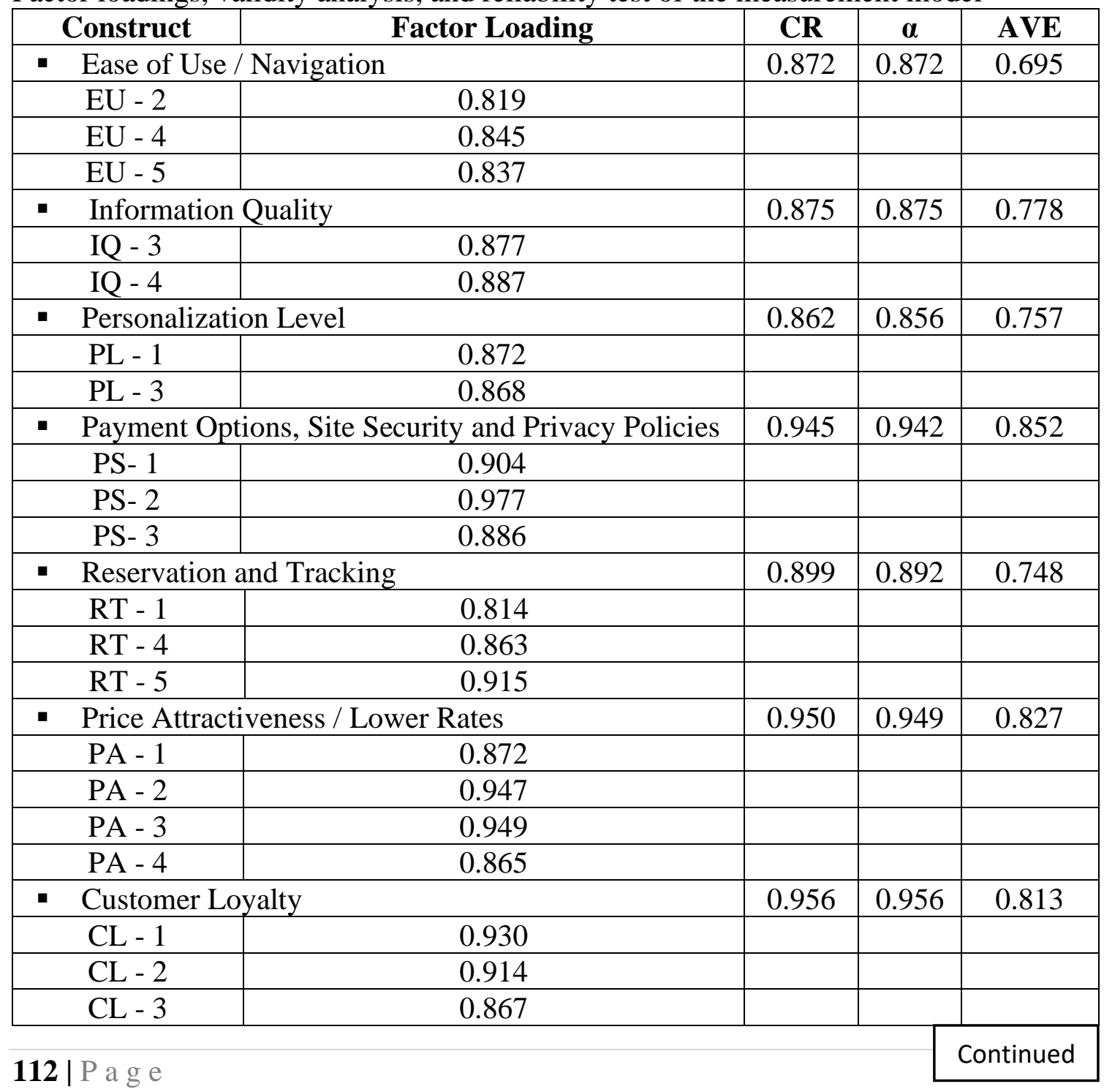




\begin{tabular}{|c|c|c|c|c|}
\hline CL - 4 & 0.913 & & & \\
\hline CL - 5 & 0.883 & & & \\
\hline Brand Image & 0.862 & 0.966 & 0.965 & 0.759 \\
\hline BI - 1 & 0.908 & & & \\
\hline BI - 2 & 0.887 & & & \\
\hline BI - 3 & 0.866 & & & \\
\hline BI - 4 & 0.840 & & & \\
\hline BI - 6 & 0.914 & & & \\
\hline BI - 7 & 0.827 & & & \\
\hline BI - 8 & 0.838 & & & \\
\hline BI - 10 & 0.894 & & & \\
\hline $\begin{array}{l}\text { Note: (CR) } \\
\text { extracted). (Composite reliability); }(\alpha)=(\text { Alpha reliability); (AVE) }=(\text { average variance }\end{array}$ \\
\hline
\end{tabular}

\section{Table 6}

Modified Model' Fitness

\begin{tabular}{|c|c|c|c|c|c|c|c|c|}
\hline & \multicolumn{7}{|c|}{ Confirmatory Factors } \\
\cline { 2 - 9 } & $(\chi 2)$ & $(\chi 2 / \mathrm{df})$ & $(\mathrm{P})$ & $(\mathrm{IFI})$ & $(\mathrm{TLI})$ & $(\mathrm{CFI})$ & $(\mathrm{RMR})$ & $(\mathrm{RMSEA})$ \\
\hline $\begin{array}{c}\text { Modified } \\
\text { (CFA) }\end{array}$ & 1450.20 & 1.782 & 0.000 & 0.953 & 0.945 & 0.952 & 0.041 & 0.053 \\
\hline $\begin{array}{c}\text { Cut-off } \\
\text { Values }\end{array}$ & $\begin{array}{c}\text { The } \\
\text { Lower } \\
\text { the } \\
\text { better }\end{array}$ & $<3$ & & & \multicolumn{7}{c|}{$>0.90$} & $\begin{array}{c}\text { The } \\
\text { Lower } \\
\text { the } \\
\text { better }\end{array}$ & $<0.07$ \\
\hline \multicolumn{10}{|c|}{ (model fit indices indicate good fit to the data) } \\
\hline
\end{tabular}

\subsubsection{Study Structural Model and Hypotheses Testing}

As a result of CFA which was discussed above, the research's proposed model was modified. More specifically, multimedia features were excluded from the model, proving that it is important to restate the research hypothesizes which were formulated and presented in Fig.1. Finally, hypotheses of the research became as follows:

H1. Ease of use / navigation (EU) has a positive impact on customer loyalty.

H2. Information quality (IQ) has a positive impact on customer loyalty.

H3. Personalization level (PL) has a positive impact on customer loyalty.

H4. Payment options, site security and privacy policies (SS) have a positive impact on customer loyalty.

H5. Reservation and tracking (RT) has a positive impact on customer loyalty.

H6. Price Attractiveness (PA) has a positive impact on customer loyalty.

H8. Customer loyalty (CL) has a positive impact on brand image (BI).

The findings revealed a strong relationship between ease of use, information quality, personalization level, payment options, site security and privacy policies, reservation and tracking, price attractiveness, and customer loyalty, Supported $H-1(B=0.431, p$ $<0.001)$; H- 2 ( $\beta=0.285, \mathrm{p}<0.001)$; H- 3 ( $\beta=0.109, \mathrm{p}<0.001)$; H- 4 ( $\beta=$ 
0.097, p < 0.050$)$; H- 5 ( $\beta=0.094, \mathrm{p}<0.050)$; H- $6(\beta=0.082, \mathrm{p}<0.050)$; respectively. In conclusion, it is noted that the eCRM features on hotels' websites have an influence on customer loyalty (see figure 2 and table 6).

Brand image was used as a dependent variable, customer loyalty was used as a moderating variable, and electronic customer relationship management included ease of use / navigation, information quality, personalization level, payment options, site security and privacy policies, reservation and tracking, price attractiveness / lower rates, multimedia features. Table 5 displays the results of hypothesis testing.

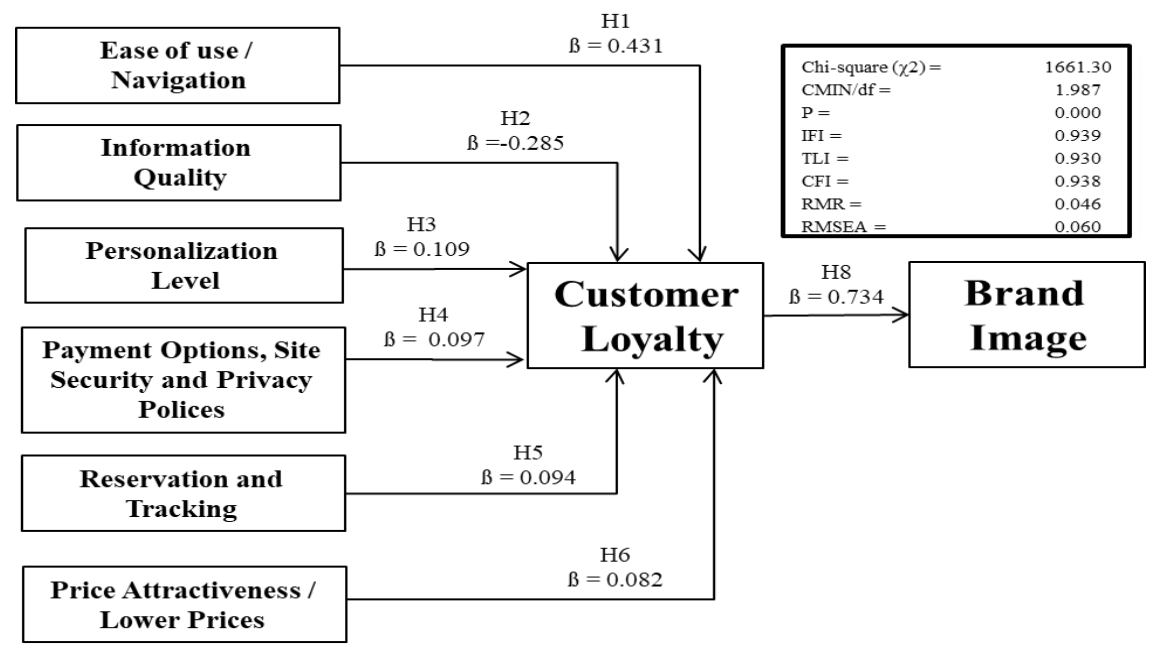

Table 5

Fig. 2. The study modified model

Standardized parameter estimates of the structural model

\begin{tabular}{|c|c|c|c|c|c|}
\hline Hyp. & (Path) & (ß) & $\begin{array}{c}(\mathrm{t}- \\
\text { values })\end{array}$ & (P) & (Results) \\
\hline H- 1 & Ease of use $\longrightarrow$ Loyalty & 0.431 & 9.428 & $* * *$ & Supported \\
\hline H- 2 & Information Quality $\longrightarrow$ Loyalty & 0.285 & 7.015 & $* * *$ & Supported \\
\hline H- 3 & Personalization Level $\rightarrow$ Loyalty & 0.109 & 4.853 & $* * *$ & Supported \\
\hline H- 4 & $\begin{array}{l}\text { Payment Options, Site } \rightarrow \text { Loyalty } \\
\text { Security and Privacy }\end{array}$ & 0.097 & 2.119 & $0.034 *$ & Supported \\
\hline H- 5 & $\begin{array}{l}\text { Reservation and } \longrightarrow \text { Loyalty } \\
\text { Tracking }\end{array}$ & 0.094 & 3.091 & $0.002 * *$ & Supported \\
\hline H- 6 & Price Attractiveness $\rightarrow$ Loyalty & 0.082 & 2.542 & $0.011 *$ & Supported \\
\hline H- 7 & Multimedia Features $\rightarrow$ Loyalty & \multicolumn{4}{|c|}{ Cancelled } \\
\hline H- 8 & Customer Loyalty $\rightarrow$ Brand Image & 0.734 & 16.674 & $* * *$ & Supported \\
\hline
\end{tabular}

Relationship between Ease of use / Navigation and Customer Loyalty

The route that connects ease of use / navigation with customer loyalty yields a significant positive coefficient value of $(\beta=0.431$, "P significant at $<0.001$ "), implying that ease of use / navigation is positively linked to customer loyalty, as expected, thereby approving $\mathrm{H} 1$. 


\section{Relationship between Information Quality and Customer Loyalty}

The route that connects information quality with customer loyalty yields a significant positive coefficient value of $(\beta=0.285$, "P significant at $<0.001$ "), implying that information quality is positively linked to customer loyalty, as expected, thereby approving $\mathrm{H} 2$.

\section{Relationship between Personalization Level and Customer Loyalty}

The route that connects personalization level with customer loyalty yields a significant positive coefficient value of $(\beta=0.109$, "P significant at $<0.001$ "), implying that personalization level is positively linked to customer loyalty, as expected, thereby approving $\mathrm{H} 3$.

\section{Relationship between Payment Options, Site Security and Privacy Policies and Customer Loyalty}

The route that connects payment options, site security and privacy policies with customer loyalty yields a significant positive coefficient value of ( $\beta=0.097$ "P significant at 0.034"), implying that payment options, site security and privacy policies are positively linked to customer loyalty, as expected, thus approving H4.

\section{Relationship between Reservation and Tracking and Customer Loyalty}

The route that connects reservation and tracking with customer loyalty yields a significant positive coefficient value of $(\beta=0.094$, "P significant at $0.002 ")$, suggesting that reservation and tracking is positively linked to customer loyalty, as expected, in this manner, approving $\mathrm{H} 5$.

\section{Relationship between Price Attractiveness / Lower Rates and Customer Loyalty}

The route that connects price attractiveness / lower rates with customer loyalty yields a significant positive coefficient value of $(\beta=0.082$ "P significant at 0.011 "), implying that price attractiveness / lower rates is positively linked to customer loyalty, as expected, thus confirming H6.

\section{Relationship between Multimedia Features and Customer Loyalty}

It can be seen from the modified final study structural model that no direct relationship between multimedia features and customer loyalty was found. The initial study model exposed a weak relationship between multimedia features and customer loyalty, but the original model did not produce an acceptable fit due to a high correlation between multimedia features and other constructs. The index suggested removing the direct path between multimedia features and customer loyalty, and the modified model produced an acceptable fit. So, it was found that multimedia features are not associated with customer loyalty in a straight line, thus cancelling H7.

\section{The Association between Customer Loyalty and Brand Image}

The route that connects customer loyalty with brand image yields a significant positive coefficient value of ( $\beta=0.734$, "P significant $0.001 ")$, implying that customer loyalty is, as expected, positively associated with brand image, thus approving $\mathrm{H} 8$.

\section{Discussion and Implications}

The current study examined the effect of electronic customer relationship management features through hotels' websites on customer loyalty and brand 
image. The results showed that electronic customer relationship management had a significant effect on customer loyalty and brand image. In general terms, and through factor investigation clients of the hotel most agreed to ease of use, information quality, personalization level, payment options, site security, privacy policies, reservation and tracking and price attractiveness. These results are come in the same line with findings stated in former marketing management researches on eCRM (Hosseini et al., 2010; Ab Hamid et al., 2011; Alhaiou, et al., 2012; Kirmaci, 2012; Rabbai, 2012; Lam et al., 2013; Muro, et al., 2013; Olupot \& Mayoka, 2013; Rabbai \& Al-Shoura, 2013; Long, et al., 2013; Tauni, et al., 2014; Alim \& Ozuem, 2014; AlRefaie, et al., 2014; Abu-Shanab \& Anagreh, 2015; Lendel \& Varmus, 2015; Tarhini, et al., 2015; Shaon, \& Rahman, 2015; Ismail \& Hussin, 2016; Mang'unyi, et al., 2017) implying that hotels need to be alerted about how customers will take in this features and its elements that would motivate loyalty to greater ranks and develop an excellent brand image.

Regarding ease of use there is a straight positive significant link between ease of use and customer loyalty was recognized $\beta=0.431$, implying that ease of use / navigation is positively influence customer loyalty in hotels. The result is in agreement with previous studies' findings (Gefen \& Straub, 2000; Venkatesh \& Davis, 2000; AlGahtani, 2001; Wu \& Wang, 2005; Nair, et al., 2007; Pai \& Tu, 2011; Behjati, et al., 2012; Vinerean, 2013; Durmuş et al., 2013). This finding could be explained the huge importance of ease of use is the degree to which the customer agrees to consume facilities with no extra charge, and it means that a visitor enjoys exploring the site for the first time and he/she accepts it as true that using a certain system will be effortless.

Moreover, information quality there is a straight positive significant link between information quality and customer loyalty was identified $\beta=0.285$, implying that information quality is positively affect customer loyalty in hotels. This is in agreement with previous studies' findings (Szymanski \& Hise, 2000; Gaurav, 2008; Liu, et al., 2008; Wang, et al., 2010, Ab Hamid et al., 2011; Dharmesti \& Nugroho, 2013). This finding may be explained by the significance of information quality on the hotel's website, as the hotel should provide accurate and up-to-date information for the facilities such as in-house rules and facilities, operating hours for specific outlets, check in / check out rules and procedures, and so on. The most essential aspect is to provide clear rates and pricing with a clear list of what is included and what is omitted from packages to avoid future misunderstandings and disputes, which may lead to distrust in online services and unhappiness and disloyalty.

Moreover, personalization level there is a straight positive significant link between personalization level and customer loyalty was identified $\beta=0.109$, implying that personalization level is favorably affect customer loyalty in hotels. This is in agreement with previous studies' findings (Rust, et al., 2000; Halimi, et al., 2011; Ab Hamid, et al., 2011; Peppers \& Rogers, 2011; Coelho \& Henseler, 2012; Alhaiou, et al., 2012; Jain, et $a l ., 2014)$. These results might be explained by the critical necessity of permitting certain amount of personalization. Most international and chain hotels enable its visitors to build a profile on their platforms, such as the hotel website and mobile applications, to configure 
personalized features for each guest, allowing visitors to notify the hotel about their hobbies, preferences, and other information such as what they prefer, what they dislike, what irritates them, and what makes them happy and content, for example ( Smoking and non-smoking rooms or floors preferences ), chosen room location, such as ( high floor room, low floor room, near elevator room, near pool room, away from any noise source, etc. ), chosen kind and size of mattress and pillows ( cotton pillow, feather pillow, gel pillow, latex pillow, bolster pillow, water pillow, or even body pillow ), unique or personalized treatment, and a space to communicate any other requests or preferences. This preference option will be available for each hotel staff to communicate with visitors even if it is their first visit to that hotel in order to better serve them, making them feel happy and increasing their loyalty. In addition, hotel visitors should be permitted to use their mobile phones to expedite check-in and check-out, as well as open locked doors, and also to request anything from any department both before and during the stay.

In addition, Payment options, site security and privacy policies there is a direct positive significant path between Payment options, site security, privacy policies and customer loyalty were identified $\beta=0.097$. Supporting that payment options, site security and privacy policies is positively influence customer loyalty in hotels, which mean that when the customer' feeling of safety and security on the website reduces they become less loyal. This is in agreement with previous studies' findings (Ho \& Wu, 1999; Heery \& Abbott, 2000; Choi \& Park, 2000; Lim \& Dubinsky, 2004; Khalifa \& Chen, 2005; Özgüven, 2011; Durmuş, et al., 2013; Ramavhona \& Mokwena, 2016; Intyaswati, 2017). This conclusion might be explained by emphasizing the critical relevance of allowing the guest to pick a preferred payment method, such as several types of credit cards. As a result, the website should offer a variety of relevant online payment options, such as Visa, Diner Club, Master Card, and American Express, in order to meet the payment method preferred by the guest. To safeguard guests' personal and financial information from being hacked or misused by anybody, the website should apply a stringent security standard to every transaction on the website. Also, without the guest's agreement, the website shall not utilize the guest's data for any reason, such as sales and marketing operations.

In terms of reservations and tracking, a straight positive significant link between reservation, tracking, and consumer loyalty was discovered $\beta=0.094$, supporting the notion that reservation and tracking have a favorable effect on client loyalty in hotels. This is consistent with the findings of prior investigations and studies (Ab Hamid et al., 2011). This finding could be explained the huge importance of online reservation and tracking system Thus, hotel' website should allow guests to view and track their transaction details and history, make changes to online reservation without much hassle, and request for services based on their preferences (tailored service). Hotel management should maintain track of their guests' online transactions, offer promotional material that is relevant to their interests, and allow visitors to build their own profiles and accounts, since this increases customer loyalty and motivates them to return.

Furthermore, there is a straight positive significant connection between price attractiveness and customer loyalty was identified $\beta=0.082$, implying that price 
attractiveness / lower prices is affect influence customer loyalty in hotels. This is in agreement with previous studies' findings (Estalami, et al., 2007; Virvilaite, et al., 2014).

This finding could be explained by the massive significance of price, which is one of the main inputs for decision making process, so while discussing with hotel guests and hotel representatives, we noticed that most international and chain hotels apply a new concern to attract guests to book through their own website or mobile app in order to save the commissions that brokers and hotel booking sites such as Booking.com, Trivago.com, Hotelscombined.com, Tripadvisor.com, Expedia.com, Hotels.com, Trip.com, Findhotel.com, Agoda.com, etc., which occasionally topped 30 percent of the rates. As a result, hotels established a policy of "Best price guarantee" to ensure that their guests are booking at the best rate through hotel platforms, and if the guest found lower rates elsewhere within 24 hours of booking, he could take a screen grab that clearly displays the lower price and corresponding price conditions and send it to the hotel within 24 hours of booking. Then customer could fill out an online claims form to request a refund of the difference, and the hotel would guarantee to match the lower rate and pay customer $25 \%$ off the competitor's rate.

Finally, there is a direct positive significant path between customer loyalty and brand image was identified $\beta=0.734$. Supporting that customer loyalty positively influence brand image in hotels. This is in agreement with previous studies' findings (Ogba, \& Tan, 2009; Andreani, et al., 2012; Yu-TeTu \& Hsu, 2013; Saleem \& Raja, 2014; Durmaz, et al., 2018). This finding could be explained the huge importance of building customer loyalty which directly build an excellent brand image.

The value of this research is the identification and prioritization of eCRM practices, which influence customer loyalty and brand image in hotels. The results show that there are statistically significant correlations between six eCRM practices and customer loyalty. In other words, eCRM practices such ease of use / navigation, information quality, personalization level, payment options, site security and privacy policies, reservation and tracking, and price attractiveness had positive impacts on customer loyalty and brand image in hotels.

As a result, the study suggests that hoteliers and hotel owners concentrate on how eCRM elements on hotel websites are built and administered. Hotels, for example, should place a greater emphasis on simplicity of use/navigation because it is very important. In general, Internet users are busy; so, site loading time, effortlessness of use, convenience, and user-friendliness are very important too.

Furthermore, hotels should pay greater attention to the quality of data given on their websites, which should be accurate and consistently updated, and their websites should include in-depth information on their services. Info presented online should mirror the actual service excellence and hotel' condition. Also, five-star hotels should allow for a high level of personalization, as well as respect consumers' needs, wishes, requests, and preferences. Allow clients to choose a favored payment way, such as numerous types of credit cards. Finally, websites for five-star hotels should be able to secure consumer personal information through the transactional gathering process. 


\section{Limitations and Future Research}

The study has several restrictions; it surveyed the effect of hotel practices of eCRM through hotel' website on customer loyalty and brand image on Greater Cairo hotels, so it may be a good chance for further researchers to study the effect of eCRM practices in restaurants, motels, resorts in cities such as Alexandria, Marsa Alam, Hurghada, Aswan, etc. Although of these restrictions, this study has beneficial suggestions for hospitality researchers and business experts.

\section{References}

- Ab Hamid, N. R., Cheng, A. Y., \& Akhir, R. M. (2011). Dimensions of E-CRM: an empirical study on hotels' web sites. Journal of Southeast Asian Research, 2011, c115.

- Abu-Shanab, E., \& Anagreh, L. (2015). Impact of electronic customer relationship management in banking sector. International Journal of Electronic Customer Relationship Management, 9(4), 254-270.

- Adejumo, A. A. (2019). Integrating Implementation Strategy, Challenges and Success Factors of CRM and e-CRM among Selected FMCG in Nigeria. International Journal of Business, 2(1), 27-35.

- Al-Gahtani, S. (2001). The applicability of TAM outside North America: An empirical test in the United Kingdom. Information Resources Management Journal (IRMJ), 14(3), 37-46.

- Alhaiou, T., Irani, Z., \& Ali, M. (2012). A study on e-CRM implementation and eloyalty at different stages of transaction cycle. International Journal of Logistics Systems and Management, 11(2), 270-284.

- Alim, S., \& Ozuem, W. (2014). The influences of e-CRM on customer satisfaction and loyalty in the UK mobile industry. Journal of Applied Business and Finance Researches, 3(2), 47-54.

- Al-Refaie, A., Tahat, M. D. A., \& Bata, N. (2014). CRM/e-CRM effects on banks performance and customer-bank relationship quality. International Journal of Enterprise Information Systems (IJEIS), 10(2), 62-80.

- Anderson, E. W., \& Mansi, S. A. (2009). Does customer satisfaction matter to investors? Findings from the bond market. Journal of Marketing Research, 46(5), 703-714.

- Anderson, E. W., \& Mittal, V. (2000). Strengthening the satisfaction-profit chain. Journal of Service research.

- Andreani, F., Taniaji, T. L., \& Puspitasari, R. N. M. (2012). The impact of brand image towards loyalty with satisfaction as a mediator in McDonald's. Jurnal manajemen dan kewirausahaan, 14(1), 64-71.

- Ata, U. Z., \& Toker, A. (2012). The effect of customer relationship management adoption in business?to?business markets. Journal of Business \& Industrial Marketing.

- Athanasopoulou, P. (2009). Relationship quality: a critical literature review and research agenda. European journal of marketing. 
- Aurier, P., \& N'Goala, G. (2010). The differing and mediating roles of trust and relationship commitment in service relationship maintenance and development. Journal of the Academy of marketing science, 38(3), 303-325.

- Azila, N., \& NoorNeeraj, M. (2011). Electronic Customer Relationship Management Performance: Its Impact on Loyalty from Customers' Perspe-ctives. International Journal of e-Education, e-Business, e-Management and e-Learning, 1(1), 1.

- Bashir, N., Papamichail, K. N., \& Malik, K. (2017). Use of social media applications for supporting new product development processes in multinational corporations. Technological Forecasting and Social Change, 120, 176-183

- Behjati, S., Nahich, M., \& Othaman, S. N. (2012). Interrelation between E-service Quality and E-satisfaction and Loyalty. European Journal of Business and Management, 4(9), 75-85.

- Bell, E., Bryman, A., \& Harley, B. (2018). Business research methods. Oxford university press.

- Bradshaw, D., \& Brash, C. (2001). Managing customer relationships in the ebusiness world: how to personalise computer relationships for increased profitability. International Journal of Retail \& Distribution Management.

- Cai, S., \& Xu, Y. (2006). Effects of outcome, process and shopping enjoyment on online consumer behaviour. Electronic Commerce Research and Applications, 5(4), 272-281.

- Cherapanukorn, V. (2017). Development of eCRM success A case study of hotel industry. International Journal of Trade, Economics, and Finance, 8(2), 90-95.

- Choi, N., \& Park, S. (2001). Development of electronic commerce user-consumer satisfaction index (ECUSI) for Internet shopping. Industrial Management \& Data Systems.

- Choi, W., Rho, M. J., Park, J., Kim, K. J., Kwon, Y. D., \& Choi, I. Y. (2013). Information system success model for customer relationship management system in health promotion centers. Healthcare informatics research, 19(2), 110.

- Chung, T. S., Wedel, M., \& Rust, R. T. (2016). Adaptive personalization using social networks. Journal of the Academy of Marketing Science, 44(1), 66-87.

- Coelho, P. S., \& Henseler, J. (2012). Creating customer loyalty through service customization. European Journal of Marketing.

- Dawn, S. K., \& Chowdhury, R. (2011). Electronic customer relationship management (E-CRM): Conceptual framework and developing a model. International Journal of Business and Information Technology, 1(1), 75-84.

- Dharmesti, M. D. D., \& Nugroho, S. S. (2013). The antecedents of online customer satisfaction and customer loyalty. Journal of Business and Retail Management Research, 7(2).

- Durmaz, Y., Çavuşoğlu, S., \& Özer, Ö. (2018). The effect of brand image and brand benefit on customer loyalty: the case of Turkey. International Journal of Academic Research in Business and Social Sciences, 8(5), 528-540.

- Durmuş, B., Ulusu, Y., \& Erdem, Ş. (2013). Which dimensions affect private shopping e-customer loyalty?. Procedia-Social and Behavioral Sciences, 99, 420427. 
- Edvardsson, B., Johnson, M. D., Gustafsson, A., \& Strandvik, T. (2000). The effects of satisfaction and loyalty on profits and growth: products versus services. Total quality management, 11(7), 917-927.

- Estalami, H., Maxwell, S., Martín-Consuegra, D., Molina, A., \& Esteban, Á. (2007). An integrated model of price, satisfaction and loyalty: an empirical analysis in the service sector. Journal of Product \& Brand Management.

- Floyd, F. J. and Widaman, K. F. (1995). Factor Analysis in the Development and Refinement of Clinical Assessment Instruments. Psychological Assessment, 7(3), 286.

- Fornell, C., Mithas, S., \& Morgeson III, F. V. (2009). Commentary-The economic and statistical significance of stock returns on customer satisfaction. Marketing Science, 28(5), 820-825.

- Gaurav, K. (2008). Impact of relationship marketing strategy on customer loyalty. The Icfaian Journal of Management Research, 7(11), 7-21.

- Gefen, D., \& Straub, D. (2000). The relative importance of perceived ease of use in IS adoption: A study of e-commerce adoption. Journal of the association for Information Systems, 1(8), 1-30.

- Gorla, N., Somers, T. M., \& Wong, B. (2010). Organizational impact of system quality, information quality, and service quality. The Journal of Strategic Information Systems, 19(3), 207-228.

- Hair, J. F., Black, W. C., Babin, B. J., Anderson, R. E., \& Tatham, R. (2006). Multivariate data analysis. Uppersaddle River.

- Halimi, A. B., Chavosh, A., Namdar, J., Espahbodi, S., \& Esferjani, P. S. (2011). The contribution of personalization to customers' loyalty across the bank industry in Sweden. In Proceedings of International Conference on Social Science and Humanity (pp. 382-386).

- Hallowell, R. (1996). The relationships of customer satisfaction, customer loyalty, and profitability: an empirical study. International journal of service industry management.

- Hamid, N. R. A., \& McGrath, M. G. (2005). The diffusion of internet interactivity on retail web sites: a customer relationship model. Communications of the IIMA, 5(2), 4.

- Harris, L. C., \& Goode, M. M. (2004). The four levels of loyalty and the pivotal role of trust: a study of online service dynamics. Journal of retailing, 80(2), 139-158.

- Heery, E., \& Abbott, B. (2000). Trade unions and the insecure workforce (pp. 167192). Routledge.

- Ho, C. F., \& Wu, W. H. (1999). Antecedents of customer satisfaction on the Internet: an empirical study of online shopping. In Proceedings of the 32nd Annual Hawaii International Conference on Systems Sciences. 1999. HICSS-32. Abstracts and CDROM of Full Papers (pp. 9-pp). IEEE.

- Hosseini, S. M. S., Maleki, A., \& Gholamian, M. R. (2010). Cluster analysis using data mining approach to develop CRM methodology to assess the customer loyalty. Expert Systems with Applications, 37(7), 5259-5264. 
- Hu, L. T., \& Bentler, P. M. (1999). Cutoff criteria for fit indexes in covariance structure analysis: Conventional criteria versus new alternatives. Structural equation modeling: a multidisciplinary journal, 6(1), 1-55.

- Intyaswati, D. (2017). The role of consumer privacy and security on brand loyalty. Jurnal InterAct, 6(2), 12-19.

- Ismail, N. A. B., \& Hussin, H. B. (2016). The effect of E-CRM features on customers satisfaction for airline e-ticket services in Malaysia. In 2016 6th International Conference on Information and Communication Technology for The Muslim World (ICT4M) (pp. 336-343). IEEE.

- Jain, K., Bhakar, S., \& Bhakar, S. (2014). Effect of Communication and Personalization on Loyalty with Trust as Mediating Variable. Prestige International Journal of Management \& IT-Sanchayan, 3(1), 1.

- Kariuki, M. N. (2015). The impact of brand image on customer satisfaction in major supermarkets in Nairobi County (Doctoral dissertation, University of Nairobi).

- Khadka, K., \& Maharjan, S. (2017). Customer satisfaction and customer loyalty: Case trivsel städtjänster (trivsel siivouspalvelut).

- Khalifa, M., \& Shen, N. (2005). Effects of electronic customer relationship management on customer satisfaction: A temporal model. In Proceedings of the 38th Annual Hawaii international conference on system sciences (pp. 171a-171a). IEEE.

- Kim, M. K., Park, M. C., \& Jeong, D. H. (2004). The effects of customer satisfaction and switching barrier on customer loyalty in Korean mobile telecommunication services. Telecommunications policy, 28(2), 145-159.

- Kirmaci, S. (2012). Customer relationship management and customer loyalty; a survey in the sector of banking. International Journal of Business and Social Science, $3(3)$.

- Lam, A. Y., Cheung, R., \& Lau, M. M. (2013). The influence of internet-based customer relationship management on customer loyalty. Contemporary Management Research, 9(4).

- Lendel, V., \& Varmus, M. (2015). Proposal of innovative approaches of relationship marketing in business. Business: Theory and Practice, 16(1), 63-74.

- Lim, H., \& Dubinsky, A. J. (2004). Consumers' perceptions of e-shopping characteristics: an expectancy-value approach. Journal of Services Marketing.

- Liu, C. C., Chuang, L. M., \& Huang, C. M. (2012). A study of the impact of the ECRM perspective on customer satisfaction and customer loyalty-exemplified by bank Sinopac. Journal of Economics and Behavioral Studies, 4(8), 467-476.

- Long, C. S., Khalafinezhad, R., Ismail, W. K. W., \& Abd Rasid, S. Z. (2013). Impact of CRM factors on customer satisfaction and loyalty. Asian Social Science, 9(10), 247

- Mang'unyi, E. E., Khabala, O. T., \& Govender, K. K. (2017). The relationship between e-CRM and customer loyalty: a Kenyan Commercial Bank case study. Banks \& bank systems, (12, No 2), 106-115.

- Milović, B. (2012). Social media and eCRM as a prerequisite for hotel success. 
- Muro, M. B., Magutu, P. O., \& Getembe, K. N. (2013). The strategic benefits and challenges in the use of customer relationship management systems among commercial banks in Kenya. European Scientific Journal, 9(13).

- Nair, C., Chan, S., \& Fang, X. (2007). A case study of CRM adoption in higher education. In Proceedings of the 2007 Information Resources Management Association International Conference.

- Ogba, I. E., \& Tan, Z. (2009). Exploring the impact of brand image on customer loyalty and commitment in China. Journal of Technology Management in China.

- Olupot, C., \& Mayoka, K. G. (2013). A framework for the adoption of electronic customer relationship management information systems in uganda. The Electronic Journal of Information Systems in Developing Countries, 58(1), 1-19.

- Oluwafemi, O. J., \& Adebiyi, S. O. (2018). Customer loyalty and integrated marketing communications among subscribers of telecommunication firms in Lagos Metropolis, Nigeria. Journal of Competitiveness, 10(3), 101.

- Özgüven, N. (2011). Analysis of the relationship between consumers' attitudes towards online shopping and their demographic characteristics. Karamanoğlu Mehmetbey University Journal of Social and Economic Research, 2011 (2), 47-54.

- Pai, J. C., \& Tu, F. M. (2011). The acceptance and use of customer relationship management (CRM) systems: An empirical study of distribution service industry in Taiwan. Expert Systems with Applications, 38(1), 579-584.

- Pallant, J. (2020). SPSS survival manual: A step by step guide to data analysis using IBM SPSS. Routledge.

- Pan, Y., \& Zinkhan, G. M. (2006). Determinants of retail patronage: a metaanalytical perspective. Journal of retailing, 82(3), 229-243.

- Peppers, D. \& Rogers, M. (2004). Managing Customer Relationships - A Strategic Framework. New Jersey: John Wiley and Sons.

- Puri, R. M. (2017). The Effect of Brand Image on Customer Satisfaction and Customer Loyalty for Wardah Local Cosmetic (Wardah Cosmetic) (Doctoral dissertation, Universitas Muhammadiyah Surakarta).

- Rabbai, R, (2012). Investigating the Impact of E-CRM on Customer Loyalty: A Case of B2B in Zain Company in Jordan. Published Thesis, Middle East University.

- Rabbai, R. A. Q., \& Al-Shoura, M. (2013). Investigating the impact of e-CRM on customer loyalty: a case of B2B in Zain company in Jordan. Middle East University.

- Ramavhona, T. C. \& Mokwena, S. (2016). Factors influencing Internet banking adoption in South African rural areas. South African Journal of Information Management, 18(2), 1-8.

- Roy, D., \& Banerjee, S. (2007). Caring strategy for integration of brand identity with brand image. International journal of commerce and management.

- Rust, R. T., \& Lemon, K. N. (2001). E-service and the consumer. International journal of electronic commerce, 5(3), 85-101.

- Rust, R. T., Zeithaml, V. A., \& Lemon, K. N. (2000). Driving Customer Equity, New York et al. Google Scholar.

- Safa, N. S., \& Ismail, M. A. (2013). A customer loyalty formation model in electronic commerce. Economic Modelling, 35, 559-564. 
- Safa, N. S., Von Solms, R., \& Furnell, S. (2016). Information security policy compliance model in organizations. Computers \& security, 56, 70-82.

- Saleem, H., \& Raja, N. S. (2014). The impact of service quality on customer satisfaction, customer loyalty and brand image: Evidence from hotel industry of Pakistan. Middle-East Journal of Scientific Research, 19(5), 706-711.

- Shaon, S. K. I., \& Rahman, H. (2015). A theoretical review of CRM effects on customer satisfaction and loyalty. Central European Business Review, 4(1), 23.

- Stojković, D., \& Đuričić, R. (2012). Customer relationship management concept in the electronic business era. Journal of Engineering Management and Competitiveness (JEMC), 2(1), 22-26.

- Szymanski, D. M., \& Hise, R. T. (2000). E-satisfaction: An initial examination. Journal of Retailing, 76(3), 309-322.

- Tarhini, A., Mgbemena, C., Trab, M. S. A., \& Masa'Deh, R. (2015). User adoption of online banking in Nigeria: A qualitative study. The Journal of Internet Banking and Commerce, 20(3).

- Tauni, S., Khan, R. I., Durrani, M. K., \& Aslam, S. (2014). Impact of customer relationship management on customer retention in the telecom industry of Pakistan. Industrial Engineering Letters, 4(10), 54-59.

- Venkatesh, V., \& Davis, F. D. (2000). A theoretical extension of the technology acceptance model: Four longitudinal field studies. Management science, 46(2), 186204.

- Vinerean, S. (2013). The Impact of Customer Perceptions and Satisfaction on ELoyalty. Expert Journal of Marketing, 1(1), 4-16.

- Virvalaite, R., Saladiene, V., \& Skindaras, D. (2009). The relationship between price and loyalty in services industry. Engineering Economics, 63(3).

- Wanjau, K. L., Kosimbei, G., Arasa, R., \& Kangu, M. (2017). Role of Customer Orientation on Customer Loyalty in the Hotel Industry in Kenya.

- Wu, J. H., \& Wang, S. C. (2005). What drives mobile commerce?: An empirical evaluation of the revised technology acceptance model. Information \& management, 42(5), 719-729.

- Yu-TeTu, Y. T., \& Hsu, T. K. (2013). The impact of brand image and customer commitment on loyalty: An empirical study of automobile sector. Information Management and Business Review, 5(4), 181-193.

- Zafar, M., Zafar, S., Asif, A., Hunjra, A. I., \& Ahmad, H. M. (2012). Service quality, customer satisfaction and loyalty: an empirical analysis of banking sector in Pakistan. Information management and business review, 4(3), 159-167. 


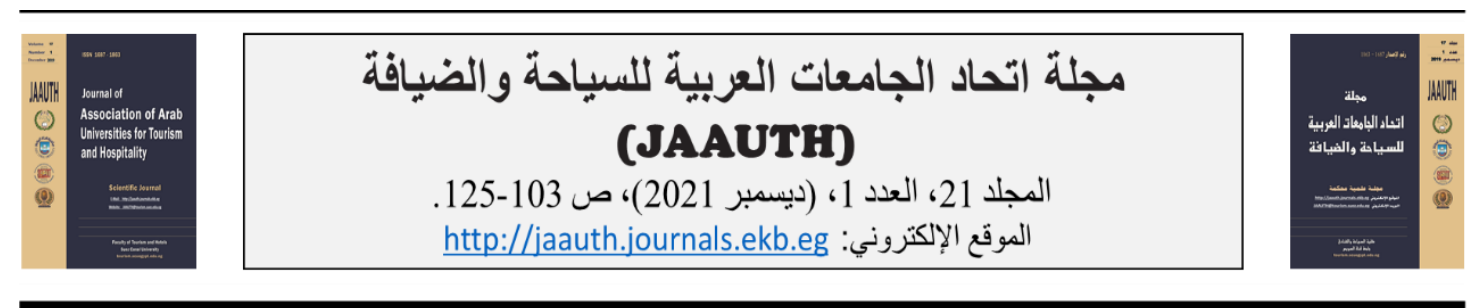

استخدام ميزات إدارة علاقات العملاء الإكترونية عبر الموقع الإكتروني للفندق لتحسين ولاء العملاء والصورة الذهنية للعلامة التجارية علية محمد أحمد كمال تامر محمد عباس ياسر إبراهيم

قسم إدارة الفنادق، كلية السياحة وإدارة الفنادق، جامعة حلوان، القاهرة، مصر مصر

\begin{tabular}{|c|c|}
\hline 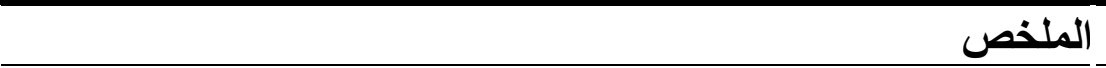 & 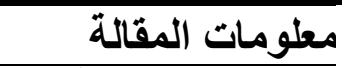 \\
\hline في صناعة الضيافة، يمكن أن تؤثر العديد من العناصر بشكل إيجابي على ولاء & الكلمات المفتاحية الكية \\
\hline العملاء والصورة الذهنية للعلامة التجارية، مثل إدارة علاقات العملاء الإلكترونية. & إدارة علاقات العملاء إلاء \\
\hline وتتألف إدارة علاقات العملاء الإككترونية عبر الموقع الإلكتروني للفندق من عدة & الإكترونية؛ ولاء \\
\hline عناصر مثل (سهولة الاستخدام والتصفح، جودة ودقة المعلومات المعروضة، مستوي & 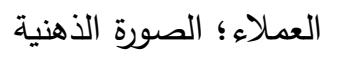 \\
\hline إضفاء الطابع الثخصي، خيارات الدفع وأمان الموقع وسياسات الخصوصية، الحجز & 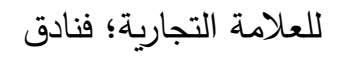 \\
\hline وتتبع الحجز، جاذبية وتنافسية الأسعار، ميزات الوسائط المتعددة). وعن طريق & القاهرة الكبري. \\
\hline البيانات التي تم جمعها من عينة من نزلاء الفنادق الخمس نجوم بالقاهرة الكبري، & \\
\hline حيث تم توزيع عدد 400 استمارة استقصاء رأي على عينة عشوائية لعملاء عدد & \\
\hline 20 فندق بالقاهرة الكبري وقد تم جمع عدد 277 استمارة صالحة للتحليل بمعدل & \\
\hline تجاوب يمثل 69.25\%. بحثت الدراسة الحالية تأثير إدارة علاقات العملاء & (ديسمبر 2021) (2021)، \\
\hline الإلكترونية على ولاء العملاء والصورة الذهنية للعلامة التجارية. تم تثكيل استبيان & 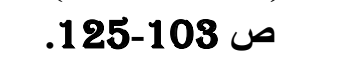 \\
\hline الدراسة الاستقصائية في هذه الدراسة بحيث يتكون الاستبيان من 45 عنصرًا مقسمة & \\
\hline إلى سبع مجموعات تتبع إدارة علاقات العملاء الإكترونية وهي سهولة الاستخدام & \\
\hline والتصفح (EU)، جودة ودقة المعلومات المعروضة (IQ)، مستوي إضفاء الطابع & \\
\hline الثخصي (PL)، خيارات الدفع وأمان الموقع وسياسات الخصوصية (PS)، الحجز & \\
\hline وتتبع الحجز (RT)، جاذبية وتتافسية الأسعار (PA)، وميزات الوسائط المتعددة & \\
\hline (MF)، بالإضافة إلي ولاء العملاء (CL) والصورة الذهنية للعلامة التجارية (BI). & \\
\hline وقد تم اختبار النموذج النظري المفترض باستخدام نمذجة المعادلة الهيكلية & \\
\hline (SEM)، وقد كثفت النتائج أن استخدام إدارة علاقات العملاء الإكترونية مثل & \\
\hline (سهولة الاستخدام والتصفح، جودة ودقة المعلومات المعروضة، مستوي إضفاء & \\
\hline الطابع الثخصي، خيارات الدفع وأمان الموقع وسياسات الخصوصية، الحجز وتتبع & \\
\hline الحجز ، جاذبية وتنافسية الأسعار ) يؤثرون بشكل كبير في ولاء العملاء. أيضًا، يؤثر & \\
\hline ولاء العملاء بشكل كبير في الصورة الذهنية للعلامة التجارية. & \\
\hline
\end{tabular}

